\title{
Effects of Deforestation on Soil Physical Properties in Nongkhyllem Wildlife Sanctuary, Meghalaya, India
}

\author{
Shafiqul I. Bhuyan*, Imrana Laskar \\ Department of Botany, Pandit Deendayal Upadhyaya Adarsha Mahavidalaya, India
}

Received March 23, 2020; Revised June 3, 2020; Accepted June 10, 2020

\begin{abstract}
Cite This Paper in the following Citation Styles
(a): [1] Shafiqul I. Bhuyan, Imrana Laskar, "Effects of Deforestation on Soil Physical Properties in Nongkhyllem Wildlife Sanctuary, Meghalaya, India," Advances in Zoology and Botany, Vol. 8, No. 5, pp. 392 - 399, 2020. DOI: 10.13189/azb.2020.080503.
\end{abstract}

(b): Shafiqul I. Bhuyan, Imrana Laskar (2020). Effects of Deforestation on Soil Physical Properties in Nongkhyllem Wildlife Sanctuary, Meghalaya, India. Advances in Zoology and Botany, 8(5), 392 - 399. DOI: 10.13189/azb.2020.080503.

Copyright $\odot 2020$ by authors, all rights reserved. Authors agree that this article remains permanently open access under the terms of the Creative Commons Attribution License 4.0 International License

\begin{abstract}
Deforestation affects the soil quality and health by means of various clearing operations, more intense exposure of the soil to weather influences, change in quality and quantity of organic matter input. Present study was undertaken to investigate the changes in soil physical properties due to deforestation, various lands clearing and subsequent land use practices in and around the Nongkhyllem Wildlife Sanctuary, Meghalaya. The sanctuary lies between $25^{\circ} 45^{\prime}-26^{\circ} 00^{\prime} \mathrm{N}$ latitude and $91^{\circ} 45^{\prime} 92^{\circ} 00^{\prime}$ E longitude. Soils from two depth $(0-15 \mathrm{~cm}$, 15- $30 \mathrm{~cm}$ ) were collected during 2018-19 from 15 selected places of three sites (Site 1 was un-disturbed, Site 2 semi-disturbed and Site 3 disturbed). Samples were analyzed with standard methodologies. Texture of the soil is dominant by the sand content and contained more than $50 \%$ of the soil as revealed by the particle size analysis. The sand percentage was found to be lowest in the deep forest $84.76 \%$ followed by semi disturbed area $86.1 \%$, then highest in deforested area $86.26 \%$. Soil particle density in the deep forest in both the depths $(0-15 \mathrm{~cm}$ and $15-30 \mathrm{~cm})$ were found to be highest as compared to the other two sites, viz., semi-disturbed site or deforested area. The soil bulk density of deep forest was found to be the lowest among the three and the deforested or the disturbed area was found to be the highest. As deforestation increased Soil moisture has reduced, bulk density increased, soil particle density decreased clay decreased and sand percentage increased. Simple correlations among soil physical properties indicate the possible reasons for changes in these properties following soil removal and subsequent deforestation.
\end{abstract}

Keywords Anthropogenic Activities, Firewood, Landslides, Land Use Changes, Leaching, Soil Conservation, Virgin Forest

\section{Introduction}

Soil physical properties mostly affect the availability of water contents, nutrients and their dynamics, oxygen to plants and sustainable productive forest growth. Different physical characteristics of soils such as soil texture, structure, bulk density, porosity, consistency, temperature, color, water content etc. are main responsible factor to affect the soil productivity. When soil filled with vital water content, it forms a perfect favorable ecosystem for the initiation and maintenance of life [1].

Anthropogenic activities in land use have altered the characteristics of the earth's surface, leading to changes in soil physic-chemical properties, soil fertility, soil erosion sensitivity and content of soil moisture. Factors responsible for soil degradation, soil quality loss are, deforestation, cultivation and irrigation, overgrazing, excessive use of chemical fertilizers, intensive cropping system, Urbanization, imbalanced nutrient application etc. in Meghalaya, north east India. Deforestation is one of the main causes for soil degradation and is an alarming threat to the economy, quality of life and future of the environment. Deforestation is primarily a concern for the developing countries as it is shrinking areas of the tropical 
forests [2] responsible for loss of biodiversity and increase the greenhouse effect [3]. Extensive and unabated deforestation, over-grazing and the growing hunger for land has hit the ecology of the country so badly that India may soon have more of waste than productive land. Deforestation takes the trees off land which can lead to instability in the ground, making fields and houses easier to create but leaving this area more susceptible to landslides, wind, and other natural weather patterns. It affects the soil quality and health by means of various clearing operations, more intense exposure of the soil to weather influences, change in quality and quantity of organic matter input. The subsequent land use determines whether the soil is offered an opportunity to regenerate or whether further stress is exerted on the soil.

Meghalaya is land of plant diversity and habitat of many endemic plant species. It has latest forest cover is $17321 \mathrm{sq}$. $\mathrm{km}$, or $77.2 \%$ of the total geographical area [4]. However, due to different factors such as increased requirement of timber and fuel wood, expansion of croplands, enhanced grazing, mining, construction of roads and slash and burn (shifting or jhum) cultivation deforestation has been going on in high rates. It is well known that the physico-chemical properties of soils and soil quality declines after removal of the forest cover. In contrast, very less attention has been given to the decline in physical attributes of the soil. On the other hand, degeneration of the soil structure may strongly limit root penetration and root functioning and may also degrade the soil fertility. This study was undertaken to investigate the changes in soil physical properties due to deforestation, various lands clearing and subsequent land use practices in and around the Nongkhyllem Wildlife Sanctuary, Meghalaya.

\section{Materials and Methods}

\subsection{Study Site}

The study was conducted in Nongkhyllem Wildlife Sanctuary located in the Ri-Bhoi district of Meghalaya. The sanctuary lies between $25^{\circ} 45^{\prime}-26^{\circ} 00^{\prime} \mathrm{N}$ latitude and $91^{\circ} 45^{\prime} \quad 92^{\circ} 00^{\prime}$ E longitude. Details sites includes Nongkhyllem Wildlife Sanctuary (2,900 ha), Nongkhyllem Reserve Forest (9,691 ha) and a portion of community forest west of the Umtrew river that is being acquired by the State Government (2,300 ha). This area is among the last large tracts of wilderness left in Meghalaya. Entire the location consisting of undulating plains to low hills, which are part of the Archaean Meghalaya Plateau. Study area has a special physical structure, especially towards west and north, because of continuous erosion by the rivers Umtrew, Umran, Umling, Umtasor and other smaller streams. Lowest parts of the Sanctuary are about $200 \mathrm{~m}$ above sea level near Lailad, while the highest are $950 \mathrm{~m}$ above sea level in the eastern and southern areas. Area has a tropical monsoon climate. Summer are hot and wet while the winters are cool and dry. Average annual rainfall is about $2,500 \mathrm{~mm}$. Mean monthly temperature varied from a maximum of $35^{\circ} \mathrm{C}$ in the month of August to a minimum of $13.3^{\circ} \mathrm{C}$ in January in the tropical landscape and a maximum temperature of $23.3^{\circ} \mathrm{C}$ in August and minimum temperature of $1.8^{\circ} \mathrm{C}$ was recorded in December in the montane subtropical landscape. Major areas of the wildlife sanctuary are Tropical Moist Deciduous forest with patches of Tropical Semi-evergreen forest, especially in the river valleys and stream. Soils of the district are loamy sand and sandy in nature, acidic, low nitrogen content and variation of organic carbon percentages among different land use patterns ${ }^{5}$. Deforestation is a common and creating huge problem in the study area. Many factors such as fire wood collection, woods for construction purpose, agriculture extension, increasing dependency of local people on forest etc. are affecting the forest quality, destroying the forest cover and biodiversity of the sanctuary specially the peripheral region. It is not only affecting the ecology, but also threats to biodiversity, socio-economy of the local as well.

\subsection{Data Collection and Analysis}

Soils from two depth $(0-15 \mathrm{~cm}, 15-30 \mathrm{~cm})$ were collected during 2018-19 from 15 selected places of three sites (Site 1 was un-disturbed, Site 2 semi-disturbed and Site 3 disturbed). Forest areas were classified into three categories as mentioned above on the basis of different parameters of disturbance and their intensity. Sampling was done by nestled plot technique. Soil samples were collected in replicate at each sampling point. Five samples were taken for each replicate. In each site, a plot of $20 \times 20$ $\mathrm{m}$ size was laid. A total of 15 soil sample replicates $(5$ from undisturbed, 5 from semi-disturbed and 5 from disturbed forest) were collected by digging soil pits using soil auger after first removing surface vegetation and litter. Different depths were taken to observe the effect of different disturbing factors on soil characteristics in details. The GPS location was recorded for each sampling point. Soil samples were weighed immediately upon returning from the field to record their fresh weight. The collected soil samples were spread on plates and air dried at room temperature $\left(30-35^{\circ} \mathrm{C}\right)$, in laboratory. After the soils completely dried, weight of whole samples was determined. Debris from soils were removed clearly, whole samples were ground and sieved through a $2 \mathrm{~mm}$ mesh. Entire sample was again weighed and mixed thoroughly again.

Soil moisture content was determined by weight loss after drying $10 \mathrm{~g}$ of soil at $105^{\circ} \mathrm{C}$ for 24 hours and expressed as percentage dry weight. Water holding capacity was determined by Keen's box method [6], Particle density was measured by method given by Huque and Alam (2005) [7]. Soil textures by Hygrometer method [8] for estimation of percentage of different fractions (sand, slit and clay). Bulk 
density was determined using the core method as described by Anderson and Ingram (1993) [9]. Porosity of the soil samples was determined indirectly from the values of Bulk Density and Particle Density. Soil data obtained in this study were analyzed using SPSS statistical package for analysis of variance (ANOVA) to compare different soil physical characteristics such as bulk density, water holding capacity, soil moisture content etc.

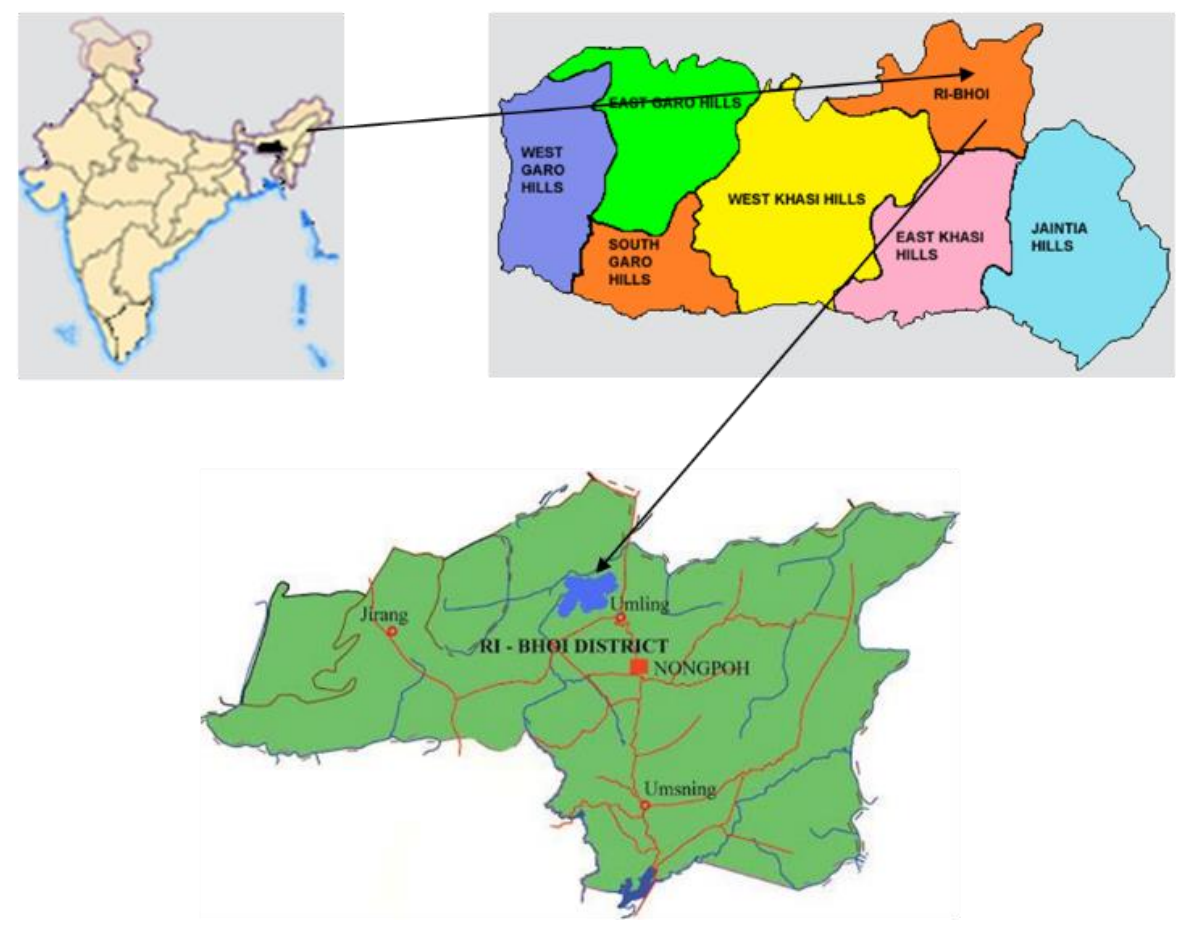

Figure 1. Map of study area in Meghalaya

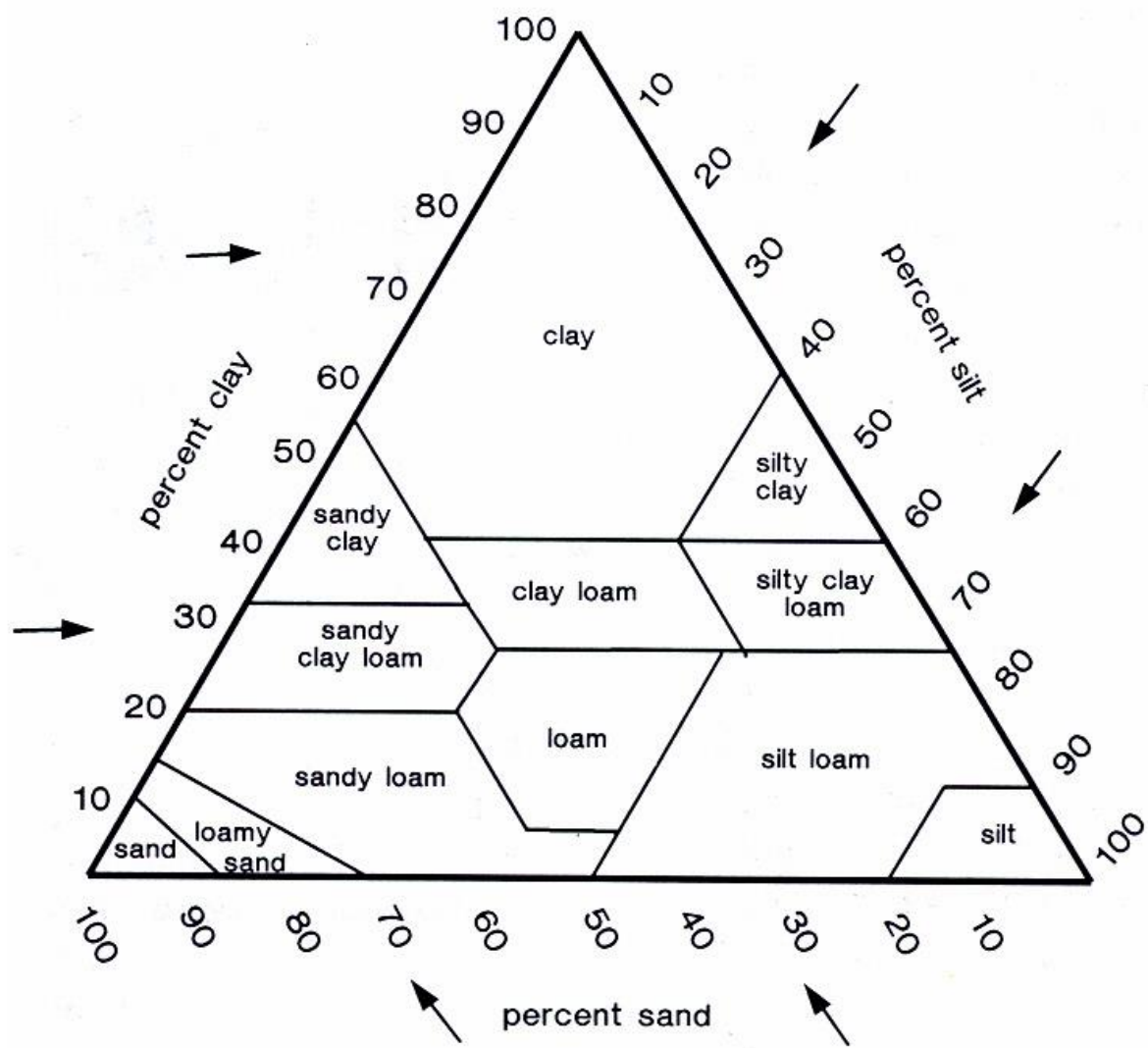

Figure 2. Soil textural triangle used for soil textural class from the percentages of sand, slit and clay in the soil as defined by the USDA. 


\section{Results and Discussion}

Soil physical properties and their changes have been studied in comparison with virgin forest (undisturbed forest) and deforested (disturbed area) in details.

\section{Soil Texture}

Texture of the soil is dominant by the sand content and contained more than $50 \%$ of the soil as revealed by the particle size analysis (table 1). The sand percentage was found to be lowest in the deep forest $84.76 \%$ followed by semi disturbed area $86.1 \%$, then highest in deforested area $86.26 \%$ and the results found by Bhuyan and Momin (2015) [10], found that the sand content in the deep forest was lowest. The overall silt percentage was found to be the second most dominant texture and was found highest in the semi disturbed area $12.73 \%$, and the deep forest and deforested area did not have much variance, however deep forest had a little lower value than the deforested i.e., with point difference $8.93 \%$ and $8.96 \%$. And the clay percentages found in the different sites $4.795 \%$ (deep forest), $4.53 \%$ (semi disturbed) and $4.38 \%$ (deforested soil) showed that deep forest had the highest percentage and the deforested area showed the lowest percentage.

\section{Soil Particle Density}

Soil particle density in the deep forest in both the depths $(0-15 \mathrm{~cm}$ and $15-30 \mathrm{~cm})$ were found to be highest as compared to the other two sites, viz., semi-disturbed site or deforested area (table 2). However, the value of the semi disturbed and deforested area was found to be more or less same as it did not have much variance and differed in point values. Soil particle density reduces if the land is deforested and remained deforested for a longer time. The inconsistency in particle density at the study site may be due to the inherent differences among the land-use patterns [11].

Table 1. Soil Texture (\%) at two depths in Deep Forest, Semi Disturbed Area and Deforested Area

\begin{tabular}{|c|c|c|c|c|c|c|c|}
\hline Forest Types & Soil texture & Soil depth $(\mathrm{cm})$ & $\begin{array}{l}\mathrm{R} 1 \\
(\%)\end{array}$ & $\mathrm{R} 2(\%)$ & R3 (\%) & Mean $(\%)$ & Average mean \\
\hline \multirow{6}{*}{ Deep forest } & Clay & & 5.40 & 4.40 & 4.40 & 4.73 & \multirow{6}{*}{$\begin{array}{c}\text { Clay }=4.79 \% \\
\text { Silt }=8.93 \% \\
\text { Sand }=84.76 \%\end{array}$} \\
\hline & Silt & $0-15$ & 13 & 12 & 6 & 10.33 & \\
\hline & Sand & & 81.60 & 83.60 & 89.60 & 84.93 & \\
\hline & Clay & & 4.80 & 5.40 & 4.40 & 4.86 & \\
\hline & Silt & $15-30$ & 7.60 & 9 & 6 & 7.53 & \\
\hline & Sand & & 87.60 & 85.60 & 89.60 & 87.6 & \\
\hline \multirow{6}{*}{$\begin{array}{c}\text { Semi } \\
\text { disturbed }\end{array}$} & Clay & & 4.40 & 4.80 & 4.80 & 4.66 & \multirow{6}{*}{$\begin{array}{l}\text { Clay }=4.53 \% \\
\text { Silt }=12.73 \% \\
\text { Sand }=86.1 \%\end{array}$} \\
\hline & Silt & $0-15$ & 8 & 6.60 & 5.60 & 6.73 & \\
\hline & Sand & & 87.60 & 88.60 & 89.60 & 88.6 & \\
\hline & Clay & & 4.40 & 4.40 & 4.40 & 4.40 & \\
\hline & Silt & $15-30$ & 16 & 10 & 10 & 12 & \\
\hline & Sand & & 79.60 & 85.60 & 85.60 & 83.6 & \\
\hline \multirow{6}{*}{$\begin{array}{l}\text { Deforested } \\
\text { area }\end{array}$} & Clay & & 4.40 & 3.80 & 4.40 & 4.1 & \multirow{6}{*}{$\begin{array}{c}\text { Clay }=4.38 \% \\
\text { Silt }=8.96 \% \\
\text { Sand }=86.26 \%\end{array}$} \\
\hline & Silt & $0-15$ & 6 & 6.60 & 10 & 7.53 & \\
\hline & Sand & & 89.60 & 89.60 & 85.60 & 87.6 & \\
\hline & Clay & & 5.80 & 3.80 & 4.40 & 4.66 & \\
\hline & Sand & $15-30$ & 12.60 & 7.60 & 11 & 10.4 & \\
\hline & Silt & & 81.60 & 88.60 & 84.60 & 84.93 & \\
\hline
\end{tabular}

R1, R2, R3, represents the replication of soil samples collected from three different sites. 
Table 2. Soil particle density of different sites

\begin{tabular}{ccccccccc}
\hline Forest types & $\begin{array}{c}\text { Soil depth in } \\
\mathrm{cm}\end{array}$ & $\mathrm{R}_{1}(\%)$ & $\mathrm{R}_{2}(\%)$ & $\mathrm{R}_{3}(\%)$ & $\mathrm{R}_{4}(\%)$ & $\mathrm{R}_{5}(\%)$ & Mean $(\%)$ & $\begin{array}{c}\text { Average } \\
\text { Mean }(\%)\end{array}$ \\
\hline Deep forest & $0-15 \mathrm{~cm}$ & 1.92 & 2.17 & 3.84 & 3.57 & 2.4 & $2.78 \pm 0.86$ & $2.46 \pm 0.22$ \\
& $15-30 \mathrm{~cm}$ & 2.22 & 2.08 & 1.81 & 2.38 & 2.27 & $2.15 \pm 0.21$ & $2.08 \pm 0.35$ \\
Semi & $0-15 \mathrm{~cm}$ & 1.96 & 1.92 & 2.04 & 1.81 & 2.7 & 2.7 & $2.05 \pm 0.02$ \\
$\begin{array}{c}\text { Disturbed } \\
\text { area }\end{array}$ & $15-30 \mathrm{~cm}$ & & 2.042 .19 & 1.88 & 1.72 & 2.3 & $2.02 \pm 0.23$ & $2.06 \pm 0.26$ \\
$\begin{array}{c}\text { Deforested } \\
\text { area }\end{array}$ & $0-15 \mathrm{~cm}$ & 1.78 & 2 & 1.85 & 2.38 & 2.3 & $2.02 \pm 0.02$ \\
\hline
\end{tabular}

\section{Bulk Density}

Table 3. Bulk density at two depths in Deep Forest, Semi Disturbed Area and Deforested Area

\begin{tabular}{ccccc}
\hline Forest types & $\begin{array}{c}\text { Soil depth } \\
(\mathbf{c m})\end{array}$ & R1 & R2 & mean \\
\hline $\begin{array}{c}\text { Deep forest } \\
\text { Semi }-\end{array}$ & $0-15 \mathrm{~cm}$ & 1.45 & 0.96 & $1.20 \pm 0.34$ \\
$\begin{array}{c}\text { disturbed } \\
\text { Deforested area }\end{array}$ & $0-15 \mathrm{~cm}$ & 1.38 & 1.09 & $1.23 \pm 0.20$ \\
\hline
\end{tabular}

Soil bulk density of deep forest was found to be the lowest among the three and the deforested or the disturbed area was found to be the highest. 1.207 in deep, 1.236 in semi, and 1.384 in deforested (table 3). The lower bulk densities indicate the soils are compacted and have more porosity, which is beneficial to root activity, water infiltration into soil, and overall growth of crops [10].

\section{Soil Moisture Content}

Soil moisture content is found to vary in different sites, the highest soil moisture retention was found in the semi disturbed area with $21.1 \%$ moisture content and the lowest moisture content was found in the deforested or the disturbed area with $11.2 \%$ (table 4). More moisture content in soil is very essential for plants and other micro-organisms as they rely heavily on water present in soils and also for nutrient cycling. However, soil moisture content varies in different places as well as seasons. Soil water affects their availability to plants and microbes for their activities, growth and development.

\section{Water Holding Capacity}

Soil water holding capacity, the amount of water can be hold for crop use. The Deforested area content more water retention capacity than the semi disturbed and the deep forest, with values $62 \%, 59.33 \%$ and $50.66 \%$ (table 5). The second highest water retention capacity was found in the semi disturbed area and the lowest water holding capacity was found in the deep forest. Higher the water holding capacity the better it is for the plant growth and optimizes crop production.

Deforestation has affected different soil physical parameters which are very important for the plant's growth and development. Soil moisture has reduced as deforestation increased, bulk density increased, soil particle density decreased, clay decreased and sand percentage increased.

Increases in bulk density generally result in decreased porosity and poor aeration which physically restrict root growth [12]. Physical soil properties affect soil structure and stability including soil permeability, sand, clay content and clay types. Soil texture is very important to determine how much water will be able to pass through the soil and soil can store. Sandy soils easily can flush more water through the root zone than clay soils. Sands posse bigger particle sizes, resulting in less surface area; correspondingly, they cannot allow as much sodium as clay particles. However, increased clay in the sub-soil could result in reduced porosity, increased water retention and reduced drainage. Simple correlations among soil physical properties (Table 6) indicate the possible reasons for changes in these properties following soil removal and subsequent deforestation. 
Table 4. Soil moisture content (\%) at two depths in Deep Forest, Semi Disturbed Area and Deforested Area

\begin{tabular}{|c|c|c|c|c|c|c|c|c|}
\hline Forest types & $\begin{array}{l}\text { Soil depth } \\
\text { (cm) }\end{array}$ & $\mathrm{R} 1(\%)$ & $\mathrm{R} 2(\%)$ & $\mathrm{R} 3(\%)$ & R4 (\%) & R5 (\%) & Mean $(\%)$ & $\begin{array}{l}\text { Average } \\
\text { mean }(\%)\end{array}$ \\
\hline \multirow{2}{*}{ Deep forest } & $0-15$ & 21 & 17 & 20 & 15 & 19 & $18.4 \pm 0.02$ & \multirow{2}{*}{18} \\
\hline & $15-30$ & 20 & 19 & 18 & 14 & 17 & $17.6 \pm 0.02$ & \\
\hline \multirow{2}{*}{$\begin{array}{c}\text { Semi- } \\
\text { disturbed }\end{array}$} & $0-15$ & 33 & 16 & 20 & 20 & 25 & $22.8 \pm 0.06$ & \multirow{2}{*}{21.1} \\
\hline & $15-30$ & 19 & 19 & 10 & 25 & 24 & $19.4 \pm 0.05$ & \\
\hline \multirow{2}{*}{ Deforested area } & $0-15$ & 10 & 14 & 7 & 16 & 9 & $11.2 \pm 0.03$ & \multirow{2}{*}{11.2} \\
\hline & $15-30$ & 17 & 4 & 7 & 14 & 14 & $11.2 \pm 0.05$ & \\
\hline
\end{tabular}

R1, R2, R3, R4, R5 represents the replication of soil samples collected from three different sites.

Table 5. Water holding capacity (\%) at two depths in Deep Forest, Semi Disturbed Area and Deforested Area

\begin{tabular}{ccccccc}
\hline Land use pattern & Soil depth & R1 (\%) & R2 (\%) & R3 (\%) & Mean (\%) & $\begin{array}{c}\text { Average mean } \\
(\%)\end{array}$ \\
\hline \multirow{2}{*}{ Deep forest } & $0-15 \mathrm{~cm}$ & 60 & 44 & 48 & $50.66 \pm 0.08$ & 50.99 \\
& $15-30 \mathrm{~cm}$ & 48 & 54 & 52 & $51.33 \pm 0.03$ & $56 \pm 0.09$ \\
Semi-deforest & $0-15 \mathrm{~cm}$ & 46 & 64 & 58 & $62.66 \pm 0.01$ & 59.33 \\
& $15-30 \mathrm{~cm}$ & 62 & 64 & 62 & $58 \pm 0.06$ & 62 \\
Deforested area & $0-15 \mathrm{~cm}$ & 64 & 58 & 52 & $66 \pm 0.08$ & 60 \\
\hline
\end{tabular}

R1, R2, R3, represents the replication of soil samples collected from three different sites.

Table 6. Correlation coefficient (' $r$ ') of soil physical properties.

\begin{tabular}{|c|c|c|c|c|c|c|c|c|}
\hline Parameter & Depth $(\mathrm{cm})$ & $\mathrm{BD}$ & WHC & SMC & Porosity & Sand & Clay & Silt \\
\hline \multirow{2}{*}{$\mathrm{BD}$} & $0-15$ & 0.32 & $-0.81 *$ & -0.60 & $0.80 *$ & 0.66 & $-0.80 *$ & -0.40 \\
\hline & $15-30$ & $0.24 *$ & -0.02 & -0.49 & -0.43 & 0.44 & -0.08 & -0.65 \\
\hline \multirow{2}{*}{ WHC } & $0-15$ & & & 0.65 & -0.61 & -0.64 & $0.78^{*}$ & 0.38 \\
\hline & $15-30$ & & & -0.69 & 0.68 & -0.43 & 0.54 & 0.20 \\
\hline \multirow{2}{*}{ SMC } & $0-15$ & & & & -0.59 & $-0.91^{*}$ & $0.87 *$ & $0.86^{*}$ \\
\hline & $15-30$ & & & & -0.13 & 0.19 & -0.44 & 0.12 \\
\hline \multirow{2}{*}{ Porosity } & $0-15$ & & & & & 0.61 & -0.68 & -0.45 \\
\hline & $15-30$ & & & & & -0.44 & 0.14 & 0.57 \\
\hline \multirow{2}{*}{ Sand } & $0-15$ & & & & & & $-0.97 *$ & $-0.94 *$ \\
\hline & $15-30$ & & & & & & $-0.82 *$ & $-0.83 *$ \\
\hline \multirow{2}{*}{ Clay } & $0-15$ & & & & & & & $0.83^{*}$ \\
\hline & $15-30$ & & & & & & & 0.36 \\
\hline
\end{tabular}

*Correlation is significant at the 0.05 level, WHC- Water holding capacity, BD- Bulk density, SMC-Soil moisture content.

Table 7. Two way ANOVA showing the effect of Forest types and soil depth on soil characters

\begin{tabular}{|c|c|c|c|c|c|c|c|c|c|}
\hline \multirow[t]{2}{*}{ Variable } & \multicolumn{3}{|c|}{$\mathrm{BD}$} & \multicolumn{3}{|c|}{ WHC } & \multicolumn{3}{|c|}{ SMC } \\
\hline & df & F-ratio & $\mathrm{P}$ & $\mathrm{df}$ & F-ratio & $\mathrm{P}$ & df & F-ratio & $\mathrm{P}$ \\
\hline Forest type & 3 & 0.315 & 0.814 & 3 & 0.777 & 0.515 & 3 & 1.535 & 0.224 \\
\hline Depth & 1 & 1.790 & 0.190 & 1 & 2.589 & 0.117 & 1 & 2.777 & 0.105 \\
\hline Forest type x Depth & 3 & 0.036 & 0.99 & 3 & 0.280 & 0.838 & 3 & 0.204 & 0.892 \\
\hline
\end{tabular}

df- degree of freedom, P-significant level.

Sand content increases in the disturbed areas in all the forest resulting decrease in nitrogen and organic matter including other particle like clay and silt. It affects the seed germination, growth and development of plants species. Effect of human activities and forest disturbance on plant diversity and soil properties was also reported by Prabhu et al. (2004) [13] in Nokrek biosphere reserve, Meghalaya. However, change of soil texture because of forest disturbing factors and hydrologic activities is achievable after an adequately elongated time. Similarly, forest fragmentation, grassland patches, over grazing might also control important properties of the soil. As a result, 
schiophytes replaced by the heliophytes because of increased sun lights and temperature in the area. The sandy nature of the disturbed forests is mainly due to soil structure changes, drainage system and less vegetation cover accelerate soil erosion in those sites. However, these changes in soil characteristics are responsible for poor growth of the forests in disturbed areas.

Different chemical properties such as soil nitrogen changed in spatial and temporal dynamics of vegetation types [14]. A similar result on Forest strata change was found in Namdopha national park due to forest exploitation by Nath et al. (2005) [15]. However, low species diversity affect the nutrients cycle in the ecosystem and other ecosystems services too $[16,17]$.

Large scale deforestation has badly affected the weather facing almost each year more of break than the normal weather. Simultaneously, over-grazing also negatively affects the regenerative capacity of the forests. Deforestation also responsible for the environment and indigenous people are loss of habitat, increased greenhouse gases, water in the atmosphere, soil erosion and flooding, destruction of homelands, poor food production, poor transportation due to landslides, loss of economy, etc. In forest the soil remains normally moist because of the amount of water retention by the roots of the trees. However, due to uproot of trees, deforestation the soil dries out easily, lost the nutrients present in top soil and which is easily taken away during floods and landslides.

It is found that main modes of deforestation in Meghalaya both in protected and unprotected area are over population of human and livestock, increased requirement of timber and fuel wood, expansion of croplands, enhanced grazing, mining, construction of roads and slash and burn (shifting or jhum) cultivation. Deforestation resulted in almost increase in bulk density, which also decrease in organic matter and total nitrogen, soluble ions comparing to the undisturbed forest soil. However, tree cover in turn, influences the improvement of physical properties of soil [18]. Tree cover also helps perpetuate the water cycle, maintain the soil health for the growth of the plants. Moreover, forests help to save the biodiversity, regulate the temperature of the land, and when they are gone the increase in the temperature of the earth can responsible for climate changes, global warming and many environmental problems.

\section{Acknowledgements}

The authors are thankful to SERB-DST, Govt. of India for financial assistant (ECR/2017/000369 Dated: 29 $9^{\text {th }}$ May, 2017). Authors are also thankful to the local people for their support during field survey.

\section{REFERENCES}

[1] Hillel, D. 1991. Research in soil physics: A re-view." Soil Science 151.1: 30-34.

[2] Barraclough, Solon L., and Krishna B. Ghimire. 2000. Agricultural expansion and tropical deforestation: poverty, international trade and land use. Earthscan.

[3] Angelsen, A., Eric F., Katemansimba S., and Jostein, A. 1999. Why do farmers expand their land into forests? Theories and evidence from Tanzania." Environment and Development Economics 4.3: 313-331.

[4] FSI. 2009. The State of Forest Report. Forest Survey of India, Ministry of Environment \& Forests, New Delhi, India.

[5] Bhuyan, S.I., Chanu, L.S. and Baruah, B.N. 2015. Impact of land use systems on soil characteristics in Ri-Bhoi district, Meghalaya. International Journal of Modern Sciences and Engineering Technology (IJMSET). ISSN 2349-3755. Volume 2, Issue 1, pp.31-36.

[6] Allen, S.E., Grimshaw, H.M., Parkinson, J.A. and Quarmby, C. 1974. Chemical Analysis of Ecological Materials. John Wiley and Sons, New York.

[7] Huque, F.M.I., and Alam, M.D.U. 2005. A handbook on analyses of soil, plant and water, Bangladesh-Australia Centre for Environmental Research (BACER-DU), Dhaka, Bangladesh, pp 246

[8] Black, C. A. 2015. Methods of Soil Analysis. Sponsored by the American Society of Agronomy and the American Society for Testing Materials. American Society for agronomy, 1965.

[9] Anderson, J.M. and Ingram, J.S.I. 1993. Tropical Soil Biology and Fertility: A Handbook of Methods. C.A.B. International, UK.

[10] Bhuyan, S.I. and Momin, K. 2015. Role of soil physical properties in Ecological restoration of coal mine land: A study in East Garo hills, Meghalaya." International Journal of Environmental Sciences 5.4 (2015): 681-687.

[11] Rahman, A., Sunil, K., Shahab F. and Masood, A. S. 2012. Assessment of land use/land cover change in the North-West District of Delhi using remote sensing and GIS techniques. Journal of the Indian Society of Remote Sensing. 40.4: 689-697.

[12] Rosenberg, N.J., and Willits. N.A. 1962. Yield and physiological response of barley and beans grown in artificially compacted soils. Soil Sci. Soc. Am. Proc. 26:78-82.

[13] Prabhu, S. D. 2004. Impact of human activities on plant biodiversity of Nokrek Biosphere Reserve of Meghalaya. PhD Thesis. North-Eastern Hill University, Meghalaya.

[14] Knapp, A. K., Blair, J. M., Briggs, J. M., Collins, S. L., Hartnett, D. C., Johnson, L. C., and Towne, E. G. 1999. The keystone role of bison in North American tallgrass prairie: Bison increase habitat heterogeneity and alter a broad array of plant, community, and ecosystem processes. BioScience, 49(1), 39-50.

[15] Nath, P. C., Arunachalam, A., Khan, M. L., Arunachalam, K., and Barbhuiya, A. R. 2005. Vegetation analysis and tree 
population structure of tropical wet evergreen forests in and around Namdapha National Park, northeast India. Biodiversity \& Conservation, 14(9), 2109-2135.

[16] Wedin, D. A., and Tilman, D. 1996. Influence of nitrogen loading and species composition on the carbon balance of grasslands. Science, 274(5293), 1720-1723.
[17] Evans, R. D., Rimer, R., Sperry, L., and Belnap, J. 2001. Exotic plant invasion alters nitrogen dynamics in an arid grassland. Ecological applications, 11(5), 1301-1310.

[18] Rathod, R., and Devar, K.V. 2003. Effect of different plantations on soil physical properties. Karnataka Journal of Agricultural Sciences 16.3: 484-485. 